\title{
Electrolyte Status in Children with Dehydration Caused by Acute Diarrhea
}

Dr. Farid Ahmed*, Dr. Mohammad Abu Morshed, Dr. Md. Abdullah Al Mamun, Dr. Muhammed Anisur Rashid, Dr. Mohammad Nazmul Ahsan

Assistant Professor, Department of Pediatric, Rangamati Medical College, Rangamati, Bangladesh

DOI: $10.36347 /$ sjams.2020.v08i08.031

| Received: 10.08.2020 | Accepted: 17.08.2020 | Published: 30.08.2020

*Corresponding author: Dr. Farid Ahmed

Abstract

Original Research Article

Introduction: Diarrhea is a condition in which faeces are discharged from the bowels frequently and in a liquid form. Dehydration is a very common phenomenon of diarrhea. Severe dehydration may cause electrolyte and acid-base imbalance in human body. So electrolyte and acid-base status analysis is a vital part of treating children with acute diarrhea. Aim of the study: The aim of this study was to evaluate the electrolyte and acid-base status in children with dehydration caused by acute diarrhea. Methods: This was a prospective observational study and was conducted in Sitakund Upazila Health Complex, Sitakund, Bangladesh during the period from January 2017 to December 2018. In total 162 children aged within 5 years admitted to the mentioned hospital with dehydration caused by acute diarrhea ware selected as the study population. Result: In our study we found $53.70 \%(\mathrm{n}=87)$ patients had isonatremic dehydration $\left(\mathrm{Na}^{+}: 135-145 \mathrm{mEq} / \mathrm{L}\right)$ followed by $44(27.16 \%)$ patients who had hyponatremic dehydration $\left(\mathrm{Na}^{+}<135 \mathrm{mEq} / \mathrm{L}\right)$. Among those $27.16 \%$ patients $4.94 \%$ had $\mathrm{Na}^{+}<120 \mathrm{mEq} / \mathrm{L}$. On the other hand, $31(19.13 \%)$ children had hypernatremic dehydration $\left(\mathrm{Na}^{+}>145 \mathrm{mEq} / \mathrm{L}\right)$. Among those $19.13 \%$ children $1.23 \%(\mathrm{n}=2)$ patients had $\mathrm{Na}^{+}>160 \mathrm{mEq} / \mathrm{L}$. Besides these, among total study population hypokalemia (serum $\mathrm{K}^{+}<3.5 \mathrm{mEq} / \mathrm{l}$ ) were in $67.90 \%$ $(n=110)$ patients and hyperkalemia (serum $\left.K^{+}>4.5 \mathrm{mEq} / \mathrm{l}\right)$ were in $6.17 \%(\mathrm{n}=10)$ patients. So $25.93 \%$ ( $\left.\mathrm{n}=42\right)$ patients had normal serum potassium level. In our study out of total 162 patients $50 \%(n=81)$ had normal $\mathrm{p}^{\mathrm{H}}$ levels $(7.35-7.45)$. We found Acidosis $\left(\mathrm{p}^{\mathrm{H}}<7.35\right)$ was present in $34.56 \%(\mathrm{n}=56)$ of patients and $15.43 \%(\mathrm{n}=25)$ cases had alkalosis $\left(\mathrm{p}^{\mathrm{H}}\right.$ $>7.45)$ in the study. Severe acidosis $\left(\mathrm{p}^{\mathrm{H}}<7.15\right)$ was present in $14.81 \%(\mathrm{n}=24)$ patients. Conclusion: The aim of this study was to evaluate the electrolyte and acid-base status in children with dehydration caused by acute diarrhea. Besides the findings regarding of this aim, socio-economic status of the participants also may be considered as a potential factor for diarrhea and dehydration.

Keywords: Electrolyte, Acid-base status, Children, Dehydration, Diarrhea.

Copyright @ 2020: This is an open-access article distributed under the terms of the Creative Commons Attribution license which permits unrestricted use, distribution, and reproduction in any medium for non-commercial use (NonCommercial, or CC-BY-NC) provided the original author and source are credited.

\section{INTRODUCTION}

Diarrhea is a condition in which faeces are discharged from the bowels frequently and in a liquid form. Dehydration is a very common phenomenon of diarrhea. Severe dehydration ma cause electrolyte and acid-base imbalance in human body. So electrolyte and acid-base status analysis is a vital part of treating children with acute diarrhea. Diarrhea is still one of the leading causes of morbidity and mortality in children around the world ${ }^{1-3}$. Oral rehydration treatment has considerably reduced complications and mortality from diarrheal diseases. Still many children with diarrhea suffer from dehydration and electrolyte imbalance ${ }^{4}$. Presence of different types of electrolyte disorders is associated with significant increase in mortality rates among children with diarrhea ${ }^{4}$. Basically diarrhea is a disease of fluid loss. Diarrhea is best defined as excessive loss of fluid and electrolyte in the stool. So, diarrhea generally causes dehydration. Acute diarrhea is sudden onset of excessively loose stools of more than $10 \mathrm{ml} / \mathrm{kg} /$ day in infants and more than $200 \mathrm{~g} / 24 \mathrm{hr}$ in older children, which lasts less than 14 days. When the episode lasts longer than 14 days, it is called persistent diarrhea [5]. Diarrheal disorders in childhood account for a large proportion (18\%) of childhood deaths, with an estimated 1.5 million deaths per year [6]. Diarrhea results in loss of sodium, chloride, bicarbonate and potassium in addition to water in stool [7]. Because diarrhea is hypotonic, water losses exceed sodium losses, potentially leading to hypernatremia. Metabolic acidosis occurs due to the loss of alkali in the gut and various other factors and potassium depletion. Besides this, metabolic acidosis causes a shift of potassium out of cells, and renal insufficiency may lead to 
hyperkalemia. A combination of mechanisms may be present; thus, it may be difficult to predict the child's acid-base status or serum potassium level from the history alone [8]. In India, study by Dastidar RG et al., from Kolkata reported prevalence of Hyponatremic dehydration $22.0 \%, 71.5 \%$ of isonatremic dehydration and $6.5 \%$ of Hypernatremic dehydration in children under 5 years of age [9]. Clinical features and management of diarrhea and dehydration will depend upon severity of dehydration, type of dehydration (isonatremic, hyponatremic and hypernatremic), nutritional status, and acid-base and electrolyte status. Present study has been planned to study on serum electrolyte and acid base disturbances in acute watery diarrhea with dehydration.

\section{OBJECTIVES}

\section{a) General objective}

- To evaluate the electrolyte status in children with dehydration caused by acute diarrhea.

\section{b) Specific Objectives}

- To evaluate the socio-economic status of the participants of the study.

\section{Methodology \& Materials}

This was a prospective observational study and was conducted in Sitakund Upazila Health Complex, Sitakund, Bangladesh during the period from January 2017 to December 2018. In total 162 children aged within 5 years admitted to the mentioned hospital with dehydration caused by acute diarrhea ware selected as the study population. The caregivers of the study subjects admitted in the pediatric unit were interviewed after taking informed written consent. Clinical examination and related laboratory investigation like serum electrolyte, ABG analysis was done. Children with acute diarrhea with gross blood in stool, age more than 5 years and patients with hypersensitivity of drug were excluded from the study. Age gender, socioeconomic status and nutritional status (as per WHO weight for height classification) were recorded. Detailed examination was done, dehydration was classified and treated as per WHO protocol and severity of illness was classified as per Vesikari scoring system for diarrheal illness. Investigation like $A B G$ analysis, serum electrolytes were done for all study subjects at the time of admission. All necessary data were collected by MS-Excel and analyzed and statistically evaluated using SPSS version 17 software. Quantitative data was expressed in mean, standard deviation while qualitative data were expressed in percentage. Statistical differences between the proportions were tested by chi square test or Fisher's exact test. 'p' value less than 0.05 was considered statistically significant. All participants were explained about the purpose of the study. Confidentiality was assured to them along with informed written consent from their parents or caregivers. The study was approved by the ethical committee of the hospital previously.

\section{RESUlT}

In our study among 162 children $87(53.70 \%)$ were male and $75(46.30 \%)$ were female. So the malefemale ratio Sitawas 1.16:1. The highest number of patients were from 1 to 2 years' age group which was $32.10 \%(n=52)$. This trend was followed by $24.69 \%$ were from 3 to 4 years' age group, $22.84 \%$ were from $>4$ years' age group and $20.37 \%$ were from $<1$ years' age group. According to the socio-economic status of the participants we found the highest number of patients were from lower class family which was $35.19 \%$ $(n=57)$. This trend was followed by $27.16 \%$ were from lower middle class, $22.84 \%$ were from upper middle class and only $14.81 \%$ were from upper class family. According to WHO classification 41 (25.31\%) children of this study had severe malnutrition, while 67 $(41.36 \%)$ had moderate malnutrition and rest of the children were in normal condition. In this study we found $117(72.22 \%)$ patients had "SOME" and 45 (27.78\%) had "SEVERE" dehydration as per WHO classification of dehydration. Among all the study people none had mild diarrheal illness as we have included hospitalized children. In this study we found, $21(12.96 \%)$ had moderately severe illness, 113 $(69.75 \%)$ had severe illness and $28(17.28 \%)$ patients had very severe illness as per Vesikari scoring of diarrhoeal illness. In our study we found $53.70 \%(n=87)$ patients had isonatremic dehydration $\left(\mathrm{Na}^{+}: 135-145\right.$ $\mathrm{mEq} / \mathrm{L})$ followed by $44(27.16 \%)$ patients who had hyponatremic dehydration $\left(\mathrm{Na}^{+}<135 \mathrm{mEq} / \mathrm{L}\right)$. Among those $27.16 \%$ patients $4.94 \%$ had $\mathrm{Na}^{+}<120 \mathrm{mEq} / \mathrm{L}$. On the other hand, $31(19.13 \%)$ children had hypernatremic dehydration $\left(\mathrm{Na}^{+}>145 \mathrm{mEq} / \mathrm{L}\right)$. Among those $19.13 \%$ children $1.23 \%(\mathrm{n}=2)$ patients had $\mathrm{Na}^{+}>160 \mathrm{mEq} / \mathrm{L}$. Besides these, among total study population hypokalemia (serum $\mathrm{K}^{+}<3.5 \mathrm{mEq} / \mathrm{l}$ ) were in $67.90 \%$ $(\mathrm{n}=110)$ patients and hyperkalemia (serum $\left.\mathrm{K}^{+}>4.5 \mathrm{mEq} / \mathrm{l}\right)$ were in $6.17 \% \quad(\mathrm{n}=10)$ patients. So $25.93 \%(n=42)$ patients had normal serum potassium level. In our study out of total 162 patients $50 \%(n=81)$ had normal $\mathrm{p}^{\mathrm{H}}$ levels (7.35-7.45). We found Acidosis $\left(\mathrm{p}^{\mathrm{H}}<7.35\right)$ was present in $34.56 \%(\mathrm{n}=56)$ of patients and $15.43 \%(n=25)$ cases had alkalosis $\left(\mathrm{p}^{\mathrm{H}}>7.45\right)$ in the study. Severe acidosis $\left(\mathrm{p}^{\mathrm{H}}<7.15\right)$ was present in $14.81 \%(\mathrm{n}=24)$ patients.

Table-1: Age distribution of participants $(\mathrm{N}=162)$

\begin{tabular}{|l|l|l|}
\hline Age (Years) & n & \% \\
\hline$<1$ & 33 & 20.37 \\
\hline $1-2$ & 52 & 32.10 \\
\hline $3-4$ & 40 & 24.69 \\
\hline$>4$ & 37 & 22.84 \\
\hline
\end{tabular}


Table-2: Socio-economic status of participants $(\mathrm{N}=162)$

\begin{tabular}{|l|l|l|}
\hline Socio-economic Status & $\mathbf{n}$ & $\mathbf{\%}$ \\
\hline Upper Class & 24 & 14.81 \\
\hline Upper Middle Class & 37 & 22.84 \\
\hline Lower Middle Class & 44 & 27.16 \\
\hline Lower Class & 57 & 35.19 \\
\hline Total & 162 & 100.00 \\
\hline
\end{tabular}

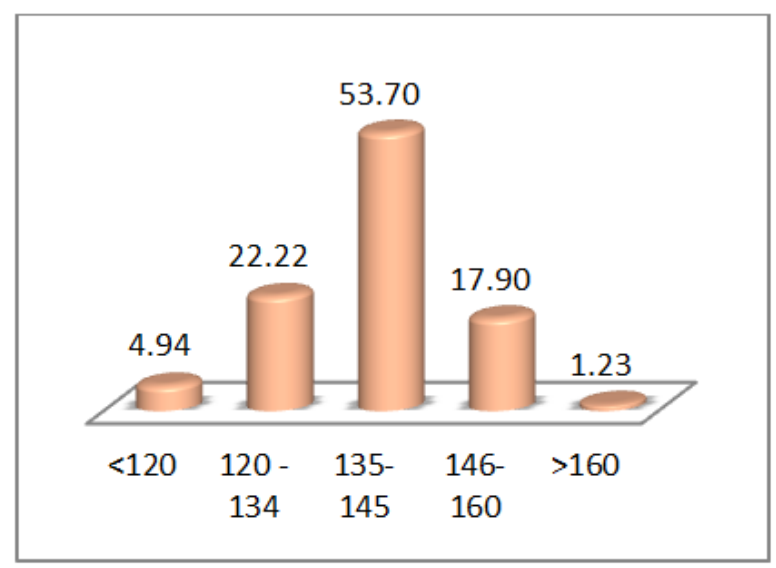

Fig-1: Sodium/ $\mathrm{Na}^{+}$level in $\mathrm{mEq} / \mathrm{L}$ distribution of participants ( $\mathrm{N}=162)$

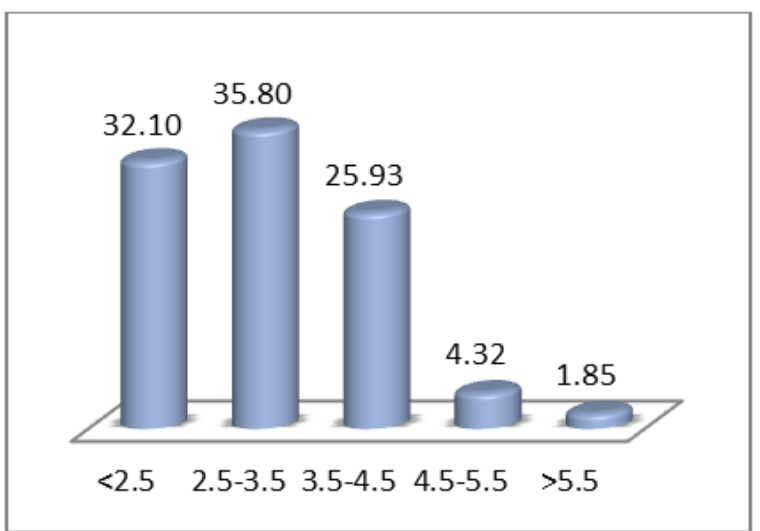

Fig-2: Potassium/ $\mathrm{K}^{+}$level in $\mathrm{mEq} / \mathrm{L}$ distribution of participants ( $\mathrm{N}=162)$

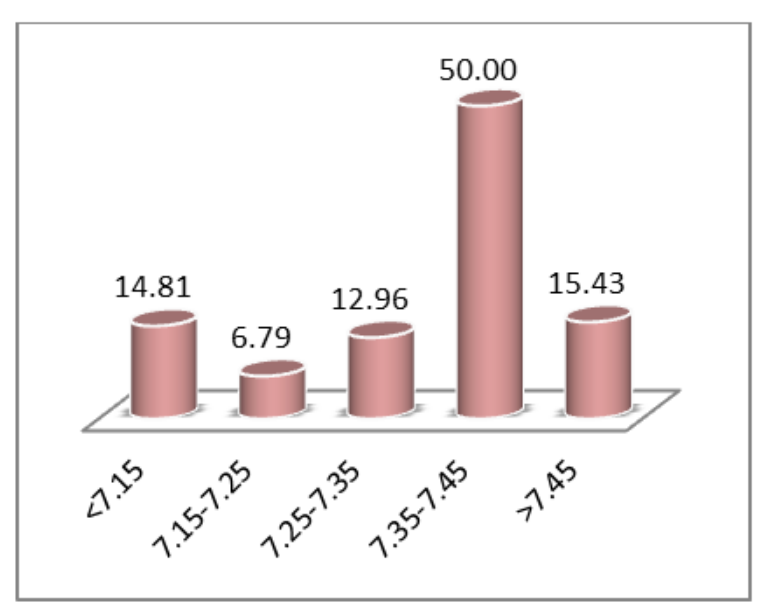

Fig-3: $p^{\mathrm{H}}$ level distribution of participants $(\mathrm{N}=162)$

\section{DISCUSSION}

The aim of this study was to evaluate the electrolyte status in children with dehydration caused by acute diarrhea. In total 162 children aged within 5 years admitted to the mentioned hospital with dehydration caused by acute diarrhea ware selected as the study population. In our study among 162 children $87(53.70 \%)$ were male and $75(46.30 \%)$ were female. So the male-female ratio was $1.16: 1$. The highest number of patients were from 1 to 2 years' age group which was $32.10 \%(n=52)$. This trend was followed by $24.69 \%$ were from 3 to 4 years' age group, $22.84 \%$ were from $>4$ years' age group and $20.37 \%$ were from $<1$ years' age group. There are some similarities in findings of us with that of another study conducted by Dagar J et al., Maharashtra, 2015 [10] and Shah GS et al., Kathmandu, 2007 [11]. According to socio-economic status of the participants in our study, the highest number of patients was from lower class family. This observation was in accordance with study by Phukan AC et al., [12]. In our study, we found $21.60 \%$ children with severe malnutrition and this observation was in accordance with study by Memon Y et al., Hyderabad [13] in which they found that electrolyte changes were commonly seen in grade II and III malnourished patients particularly who presented with diarrhoeal episode of variable duration. As per WHO classification of dehydration in our study we found 117 (72.22\%) patients had "SOME" and 45 $(27.78 \%)$ had "SEVERE" dehydration. Similar observations were found in the study conducted by Okposio MM et al., Benin, 2015 [14] in which Electrolytes and acid base disturbances were observed in $165(89.2 \%)$ of the children, most of them (114 or $61.6 \%$ ) were moderately dehydrated, while mild and severe dehydration accounted for $41(22.2 \%)$ and 30 (16.2\%), respectively. Another study by Dastidar RG et al., [9] reported that out of 200 children 166 cases $(83 \%)$ had moderate dehydration, whereas 34 cases $(17 \%)$ had severe dehydration which was also near to our study. In our study we found $53.70 \%(\mathrm{n}=87)$ patients had isonatremic dehydration (Na+: $135-145 \mathrm{mEq} / \mathrm{L}$ ) followed by $44(27.16 \%)$ patients who had hyponatremic dehydration $(\mathrm{Na}+<135$ $\mathrm{mEq} / \mathrm{L})$. Tis findings is compareable with the study conducted by Okposio MM et al., [14] where dehydration was the most common type of dehydration (60.5\%), while hypokalaemia occurred in 82 (44.3\%). Metabolic acidosis was reported in $59.5 \%$ children. Dastidar RG et al., Kolkata [14] revealed that $71.5 \%$ had Isonatremia, 22\% had Hyponatremia and 6.5\% had Hypernatremia. Hypokalemia was present in $15 \%$ (30) cases and $85 \%$ (170) cases had Normokalemia. Ahmad MS et al., Pakistan, 2012 [15] found that hyperchloremia was the commonest electrolyte disorder $(53.8 \%)$, followed by hyperkalemia $(26.9 \%)$ and hypernatremia $(17.3 \%)$. Hyponatremia, hypokalemia and hypochloremia were present in $10.6 \%, 7.7 \%$, and $10.6 \%$ cases, respectively. In this study hypernatremia was more common than hyponatremia. It may be due to the fact that the author selected participants from birth to 18 years of age, while in our study we have included 
subjects till 5 year of age. Other study By Purohit KR et al., Andhra Pradesh [16] and Dagar J et al., Maharashtra, 2015 [10] also reported higher incidence of hyponatremic dehydration and metabolic acidosis. During our intervention in article review we found some differences of our findings with that of many published studies conducted on younger children and adolescents. So age may be a potential factor in this issue.

\section{Limitations of the study}

This was a single centered study with a small sized sample. So the findings of this study may not reflect the exact scenario of the whole country.

\section{CONCLUSION AND \\ RECOMMENDATIONS}

The aim of this study was to evaluate the electrolyte status in children with dehydration caused by acute diarrhea. Besides the findings regarding of this aim, socio-economic status of the participants also may be considered as a potential factor for diarrhea and dehydration. For getting more specific information we would like to recommend for conducting more studies regarding the same issue with larger sized sample.

\section{REFERENCES}

1. Black RE, Cousens S, Johnson HL, Lawn JE, Rudan I. Global, regional, and national causes of child mortality in 2008: a systematic analysis. Lancet. 2010; 375:1969-87.

2. Chola L, Michalow J, Tugendhaft A, Hofman K. Reducing diarrhoea deaths in South Africa: costs and effects of scaling up essential interventions to prevent and treat diarrhoea in under-five children. BMC Public Health. 2015; 15:394.

3. Escobar AL, Coimbra CE Jr, Welch JR, Horta BL, Santos RV, Cardoso AM. Diarrhea and health inequity among indigenous children in Brazil: results from the First National Survey of Indigenous People's Health and Nutrition. BMC Public Health. 2015; 15:191.

4. Shah GS, Das BK, Kumar S, Singh MK, Bhandari GP. Acid base and electrolyte disturbance in diarrhoea. Kathmandu Univ Med J (KUMJ). 2007; 5:60-2.

5. Sreedharan R, Liacouras CA. Major Symptoms and signs of digestive tract disorders. Nelson
Textbook of Pediatrics. 20th ed. Philadelphia. Elsevier Publishers; 2016: 1761.

6. Nelson EA, Tam JS, Bresee JS, Poon KH, Ng $\mathrm{CH}$, Ip KS. Estimates of Rotavirus Disease Burden in Hong Kong: Hospital-Based Surveillance. J Infect Dis. 2005; 192 Suppl1:S71-9.

7. Molla AM, Rhman M, Sarker SA, Sack DA, Molla A. Stool electrolyte content and purging rates in diarrhea caused by rotavirus, enterotoxigenic E. coli and V. cholerae in children. The Journal of pediatrics. 1981 May 1;98(5):835-8.

8. Greenbaum LA. Electrolyte and acid-base disorders. Nelson Textbook of Pediatrics. 20th ed. Philadelphia. Elsevier Publishers; 2016:34691.

9. Dastidar RG, Konar N. A Study of Electrolyte Disturbances in a Child Presenting with Acute Gastroenteritis, with Special Emphasis on Hyponatremic Dehydration-A Hospital based Cross-Sectional Study. Pediatr Ther. 2017: 2;322.

10. Dagar J, Shah P, Koppad AM, Singh S. To study serum electrolyte profile in 1 month-5 years children with dehydration admitted to Kimsdu hospital, Karad. J Evol Med Dent Sci. 2016; 5:7263-6.

11. Shah GS, Das BK, Kumar S, Singh MK, Bhandari GP. Electrolyte disturbances in diarrhea. Pediatric Oncall Journal. 2006; 3:39.

12. Phukan AC, Patgiri DK, Mahanta J. Rotavirus associated acute diarrhoea in hospitalized children in Dibrugarh, north-east India. Indian J Pathol Microbiol 2003; 46:274-8.

13. Memon Y, Majeed R, Ghani MH, Shaikh S. Serum electrolyte changes in malnourished children with diarrhoea. Pak J Med Sci. 2007; 23:760.

14. Okposio MM, Onyiriuka AN, AbhulimhenIyoha BI. Point-of-Admission Serum Electrolyte Profile of Children less than Five Years Old with Dehydration due to Acute Diarrhoea. Trop Med Health. 2015; 43:247-52.

15. Ahmad MS, Wahid A, Ahmad M, Mahboob N, Mehmood R. Prevalence of Electrolyte Disorders Among Cases of Diarrhea with Severe Dehydration and Correlation of Electrolyte Levels with Age of the Patients. J Coll Physicians Surg Pak. 2016; 26:394-8.

16. Purohit KR, Jyotsna PSR. Electrolyte disturbances in acute diarrhoea. Ind Journal Pediatrics. 1971; 38:393. 